\title{
Türkçe işaret sözcükleri dizgesi üzerine bazı notlar ${ }^{1}$
}

\section{Metin BALPINAR²}

\begin{abstract}
APA: Balpınar, M. (2019). Türkçe işaret sözcükleri dizgesi üzerine bazı notlar. RumeliDE Dil ve
\end{abstract} Edebiyat Araşturmaları Dergisi, (16), 27-39. DOI: 10.2900o/rumelide.616882

\section{$\ddot{O} \mathbf{z}$}

Bu çalışmada, Türkiye Türkçesindeki işaret sözcüklerinin çeşitli kullanımları, ilk kez, durumsal, algısal ve metne bağlı özelliklerine ayrılarak incelenmiştir. Durumsal kullanımda (durum bağlamında bulunan nesneleri işaret eden kullanımda), bu ve şu sözcükleri, o'dan farklı bir dağılımsal özellik göstermektedir; bu ve şu konuşucunun alan içinde bulunan göndergeye işaret ederken, $o$ konuşucunun alanı dışında kalan göndergeye işaret eder. Algısal kullanımda (konuşucunun ve dinleyicinin ortak bilgisine dayalı işaret sözcüğü kullanımda) da, durumsal kullanımdakine benzer bir biçimde, şu ve $o$ işaret sözcüklerinin dağılımı konuşucunun alanı kavramına duyarlıdır. Metne bağh kullanımda (işaret sözcüğünün, söylem içinde kendinden önce gelen bir tümceye ya da ad öbeğine gönderimde bulunduğu kullanımda), bu kendinden önce gelen bir önermeyi, $o$ kendinden önce gelen bir ad öbeğini işaretler. Ayrıca, $o$ işaret sözcüğü, bu sözcüğünde görülmeyen, bir niceleyici tarafından bağlanan mantıksal değişken olma özelliğine sahiptir. Araştırmanın bulguları bize, Türkçe işaret sözcükleri dizgesiyle ilgili şunları göstermektedir: (a) durumsal kullanımda, Türkçe işaret sözcükleri iki sırası bitişik olan ikili bir karşıtlık ilişkisi ( $b u$ şu / o) sergilemektedir, (b) Türkçe işaret sözcüklerinin algısal ve metne bağlı kullanımlarında ise ikili karşıtlık dizgeleri (algısal kullanımda 'şu / o' ve metne bağlı kullanımda 'bu / o' dizgeleri) göze çarpmaktadır.

Anahtar kelimeler: Türkçe, işaret sözcükleri, durumsal kullanım, algısal kullanım, metne bağlı kullanım.

\section{Some notes on the system of Turkish demonstratives}

\begin{abstract}
In this study, various usages of modern Turkish demonstratives have been first time examined by dividing into situational, recognitional and anaphoric characteristics. In the situational use (in a demonstrative use which indicates an object in the situational context), bu and şu show a distinctive distributional property unlike the demonstrative $o: B u$ and şu refer to the object which is within the speaker's space while $o$ refers to the object which is outside of the speaker's space. In the recognitional use (in a demonstrative use which is based on a specific shared knowledge between the interlocutors), the distribution of the demonstratives şu and $o$ are sensitive to the concept of speaker's space like their situational counterparts. In the text-dependent use (in a use where a demonstrative refers to a proposition or a noun phrase in the discourse), $b u$ marks a proposition and $o$ marks a noun phrase in the preceding discourse. Besides, unlike the demonstrative $b u, o$ has a feature of being a logical variable bounded by a quantifier. Regarding the demonstrative system, our findings show that (a) in the situational use, Turkish demonstratives exhibit a dichotomous relation where two series
\end{abstract}

$1 \quad \mathrm{Bu}$ çalışma, yazarın 2006 yllında Reitaku Üniversitesi’nde verdiği yayımlanmamış yüksek lisans tezinin güncel kaynaklarla revize edilmiş ve düzenlenmiş halidir.

2 Dr. Öğr. Üyesi, Burdur Mehmet Akif Ersoy Üniversitesi, Fen Edebiyat Fakültesi, Doğu Dilleri ve Edebiyatları Bölümü (Burdur, Türkiye), mbalpinar@mehmetakif.edu.tr, ORCID ID: 000o-00o3-0998-2963 [Makale kayit tarihi: 27.05.2019kabul tarihi: 18.09.2019; DOI: 10.29000/rumelide.616882] 
appear to be placed contiguously (e.g. $b u$ şu / o), (b) as for the recognitional and text-dependent uses of Turkish demonstratives, the dichotomic series 'şu / $o$ ' in the recognitional use and ' $b u$ / $o$ ' in the text-dependent use occur.

Key words: Turkish, demonstratives, situational use, recognitional use, text-dependent use.

\section{Giriş}

Türkiye Türkçesi, bu-, şu- ve $o$ - köklerinden oluşan üç sıralı bir işaret sözcükleri dizgesine sahiptir (bkz. Tablo 1).

Tablo 1. Türkiye Türkçesindeki işaret sözcükleri

\begin{tabular}{|c|c|c|c|c|}
\hline \multirow[b]{2}{*}{ issaret sözcüğü kökü } & \multicolumn{4}{|c|}{ gönderge türü } \\
\hline & nesne/kişi & yer & slklık/miktar & durum \\
\hline bu- & $b u$ & bura & bunca & böyle \\
\hline şu- & şu & şura & şunca & şöyle \\
\hline$O^{-}$ & $o$ & ora & onca & öyle \\
\hline
\end{tabular}

Bu sözcükler arasında, nesneyi/kişiyi işaretleyen $b u$, şu ve $o$ işaret sözcükleri, adılların ve niteleyicilerin tüm özelliklerine sahiptir. Yer belirten bura, şura, ora sözcükleri adıl; sıklı/miktar bildiren bunca, şunca, onca sözcükleri ad niteleyici; durum bildiren böyle, şöyle, öyle sözcükleri de bulundukları sözdizimsel bağlama göre ad niteleyici ya da belirteç işlevi görürler. Bu çalışmada, tartışmanın daha sade ve anlaşlır bir biçimde ele alınabilmesi amacıyla, sadece nesne/kişi ve yer bildiren işaret sözcüklerine yer verilerek bu sözcüklerin çeşitli kullanım özellikleri ile dizge yapıları üzerinde durulacaktır.

\section{Türkçe işaret sözcükleri ve dizgesiyle ilgili çalıșmalar}

Türkçe işaret sözcükleri üzerine yapılmış olan çalışmaları üç ana grupta toplamak mümkündür: (a) temelde tek bir kritere göre işaret sözcükleri dizgesini üçe ayıran yaklaşım (üçlü ayrım), (b) üçlü dizgeyi önce bir kritere göre ikiye karşı bir parçaya ayırıp sonra farklı bir kriter kullanan yaklaşım (ikili ayrım; bu grup içinde ' $b u$ şu / o' ve ' $b u$ o / şu' karşıtlıkları bulunmaktadır), (c) iki farklı kriter kullanarak 'bu şu / o' ve 'bu o / şu' karşıtlıklarını birleştiren yaklaşım.

Literatürde, (a)'da belirtilen yaklaşımda, işaret sözcüklerinin dağılımını belirlemek için, iki farklı kriter kullanıldığı görülmektedir: Göndergenin konuşucuya olan mesafesi ve kişi zamiri. İlk kriteri kullanan yaklaşıma göre, $b u$ konuşucuya yakın, şu konuşucudan biraz uzak ve $o$ konuşucudan uzak nesneyi işaret eder (Ergin, 1958; Lewis, 1967; Iinuma, 1995; Banguoğlu, 2004). İkinci kriteri kullanan yaklaşıma göre ise, $b u$ konuşucuya yakın, şu dinleyiciye yakın, $o$ hem konuşucuya hem de dinleyiciye yakın olmayan nesneyi işaret etmek için kullanılır (Kissling, 1960; Bazin, 1968). Ancak, (a)'daki yaklaşım, söz konusu göndergenin konuşucudan biraz uzakta (başka bir deyişle orta mesafede) olduğunun nasıl belirlenebileceği sorusunu da beraberinde getirmektedir. Ayrıca, dinleyiciye yakın olan nesnelerin konuşucu tarafından şu değil de $o$ ile işaretlenebilmesi, $b u$, şu ve o'nun gösterimsel kullanımlarının sırasıyla 1., 2. ve 3. kişi zamirleriyle ilişkilendirilmesini güçleştirmektedir.

Yukarıda belirtilen sorunların üstesinden gelebilmek amacıyla, (b)'deki yaklaşımı temel alan araştırmalardan bazıları dikkate değerdir (Bastuji, 1976; Hayasi, 1985). Bastuji (1976), iletişim alanı (l'espace de la communication) kavramını ortaya atarak, bu ve şu'nun iletişim alanı içindeki nesneleri, o'nun ise iletişim alanı dışındaki nesneleri işaretlediği fikrini ileri sürmüştür. Ayrıca, iletişim alanı kategorisi içinde bulunan bu ve şu'nun kullanımıyla ilgili olarak Bastuji, (i) konuşucunun alanı/zamanı 
ile ilişkilendirilebilmesi bakımından bu'nun dönüşlü deiktik (vurgusuz) özelliğe sahip olduğunu, (ii) konuşucunun kendi alanı/zamanına ilişkin değişimleri anlatmasına karşın, onları dinleyiciye göstermesi açısından şu'nun geçişli deiktik (vurgulu) özelliğe sahip olduğunu belirtmektedir. Hayasi (1985, 1989), söylem kavramından yararlanarak, Türkçe işaret sözcüklerinin durumsal ve metne bağlı kullanımlarına birleştirici bir açıklama getirmeye çalışmıştır. Hayasi'ye göre, şu göndergeyi söylem ortamına getirmek için kullanılırken, $b u$ ve $o$ söylem ortamına getirilmiş olan bir göndergeye gönderimde bulunmak için kullanılmaktadır. Ayrıca, Hayasi, bu ve $o$ arasındaki ayrımla ilgili olarak, bu'nun mekânsal ya da psikolojik olarak konuşucuya yakın olan göndergeyi, o'nun mekânsal ya da psikolojik olarak konuşucuya uzak olan göndergeyi işaretlediğini belirtmektedir.

Yukarıda (c)'de belirtilen yaklaşım ise, Bastuji (1976)'nın 'bu şu / o' ve Hayasi (1985)'in 'bu o / şu' karşıtlıklarını birleştiren bir yaklaşımdır. Hayasi (1988), 1985 yılındaki çalışmasında (Hayasi, 1985) öne sürdüğü 'göndergenin söylem içinde bulunup bulunmadığı' kriteriyle Bastuji (1976)'nın 'göndergenin iletişim alanı içinde bulunup bulunmadığı' kriterini kullanarak, $b u$, şu ve $o$ işaret sözcüklerinin dağılımlarını Şekil 1'de görüldüğü biçimde betimlemeye çalışmıştır.

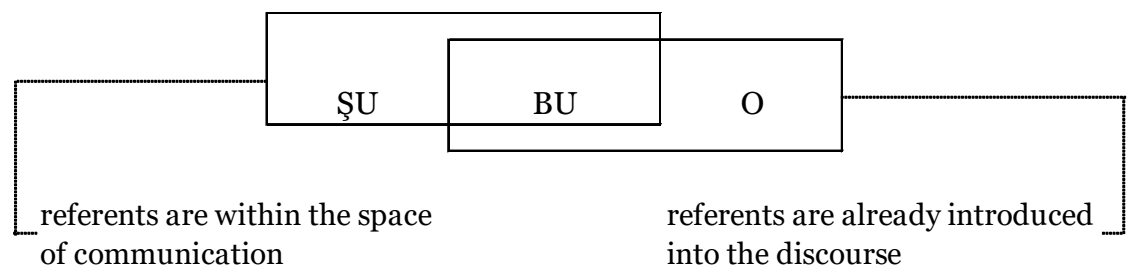

Şekil 1. Hayasi (1988, s. 236)’a göre Türkçe işaret sözcüklerinin dağılımı

Şu ana kadar, Türkçe işaret sözcükleri dizgesi üzerine yapılmış olan başlıca çalışmalara kısaca değindik. Bunların içerisinde, (i) Bastuji (1976)'da iletişim alanı kavramının açıkça tanımlanmamış olması, (ii) Hayasi (1985, 1989)'da mekânsal ya da psikoloji mesafe şartının artıklı̆̆a neden olması, (iii) literatürde (a)-(c)'de belirtilen yaklaşımlarla açıklanamayan çeşitli işaret sözcüğü kullanımlarının bulunması, Türkçe işaret sözcüğü dizgesinin yeniden incelenmesini gerekli kılmaktadır. ${ }^{3}$

Bu çalışmada, yakın zamandaki çalışmalardan farklı olarak, şu ana kadar üzerinde durulmamış, nesne/kişi ve yer bildiren Türkçe işaret sözcüklerine ait çeşitli kullanımlar Şekil 2'de gösterilmiş olan durumsal, algısal ve metne bağlı kullanımlarına ayrılarak incelenecek ve Türkçe işaret sözcükleri dizgesi betimlenmeye çalışlacaktır.

Hayasi (1895, 1989)'daki mesafe şartı, $A$ ya da B şeklinde ifade edilmiş olduğundan 'bir durumda, A'nın da B'nin de
kullanılması mümkündür' anlamında artıkh̆ğa (redundancy) sahiptir. Bu açıdan, bu şartın doğru bir genelleme olamayacağını söylemek mümkündür. 


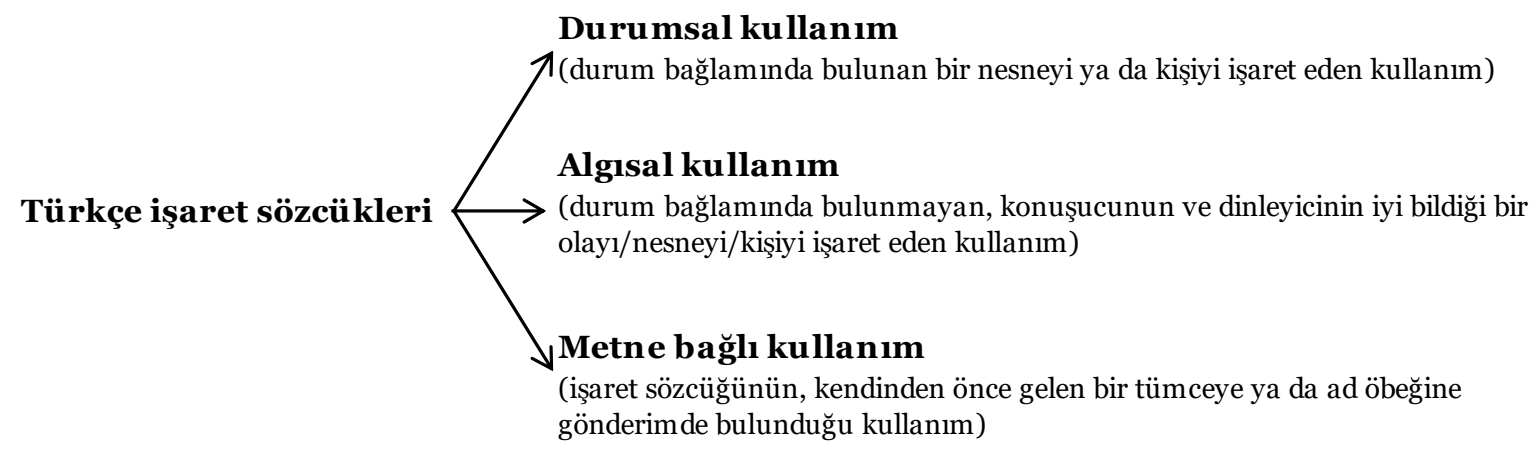

Şekil 2. Türkçe işaret sözcüklerinin sınıflandırılması

\section{Durumsal kullanım}

Türkçe işaret sözcükleri üzerine yakın zamanda yapılmış olan çalışmalar (Balpınar, 2014), durumsal kullanımda $b u$, şu ve o'nun dağılımını belirlemede, konuşucunun alanı ve dinleyicinin algısı kavramlarının işlevsel olduğunu göstermektedir. Balpınar (2014)'e göre bu ve şu sözcükleri konuşucunun alanı içinde kalan göndergeyi, $o$ konuşucunun alanı dışında kalan göndergeyi işaretler. Ayrıca, Balpınar, $b u$ ve şu arasındaki ayrımı belirlemede dinleyicinin algı durumunun da etkili olduğunu rapor etmektedir; dinleyicinin göndergenin farkına vardığı durumlarda $b u$, dinleyicinin göndergenin henüz farkına varmadı̆̆ı durumlarda şu kullanılmaktadır. Bu yaklaşım, Şekil 3'de özetlenmiştir.

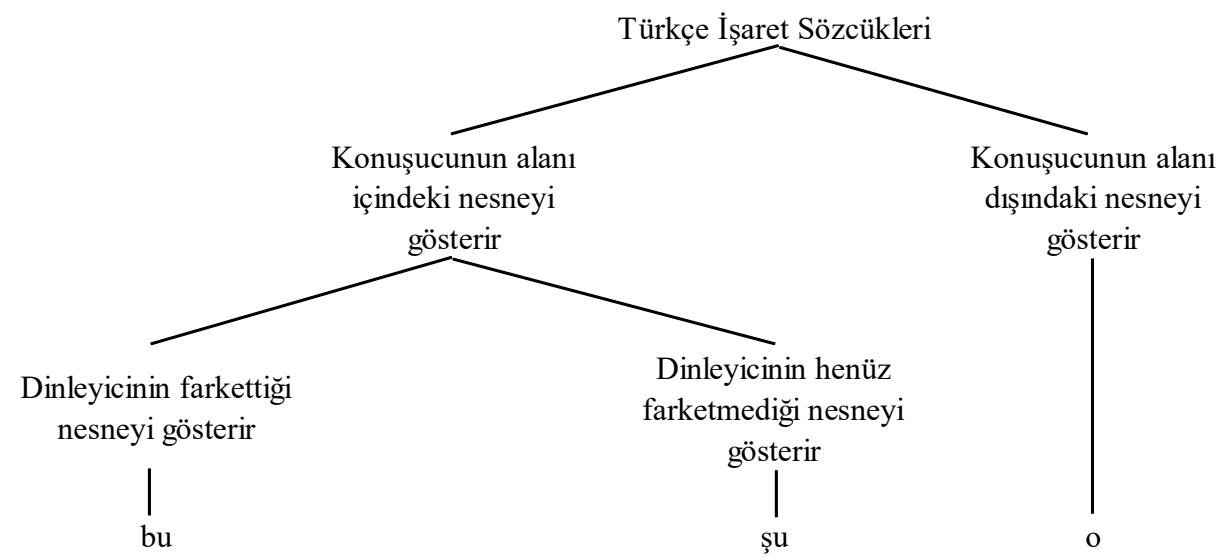

Şekil 3. Durumsal kullanımda Türkçe işaret sözcükleri ayrımı

Balpınar (2014), durumsal kullanımda Türkçe işaret sözcüklerinin dağılımını belirleyen konuşucunun alanı ve dinleyicinin algısı kavramlarını şu şekilde tanımlamaktadır:4

「話し手の空間」：話し手による自由なアクセス (利用)が制限されておらず、従って話し手による 指示対象にかかわる円滑な指示行為の遂行が期待できる空間である。(Konuşucunun alanı: Konuşucu tarafından göndergeye serbest erişimin (kullanımın) kısıtlanmadığı ve böylece göndergeyle ilişkili gönderimsel davranışın sorunsuzca yerine getirilmesi beklenen alan.) (Balpınar, 2014, s. 29)

4 Bu çalıșmadaki tüm ingilizce ve Japonca metinler yazar tarafından Türkçeye çevrilmiștir. 
「聞き手による認識」：聞き手が指示対象の存在に気付いているかどうかと言う話し手による判断 である。(Dinleyicinin algısı: Dinleyicinin göndergeyi fark edip fark etmediğine ilişkin konuşucunun vermiş olduğu karar.) (Balpınar, 2014, s. 23)

Bu kavramların nasıl işlediğini görmek için şu örneklere bir göz atalım. Önce, konuşucunun alanı kavramını ele alalım.

(1) (Konuşucu, bilgisayar oyunu oynayan dinleyicinin arkasından seslenerek, ondan, yanına yuvarlanmış olan yumağı kendisine vermesini ister)

$\left\{{ }^{*} \mathrm{bu} / \mathrm{şu} /{ }^{*} \mathrm{o}\right\}$ yumağı verir misin? (Nisioka, 2006, ss. 63-64)

(1') (Konuşucu, elindeki yumağı sarmakta olan dinleyiciye seslenerek söz konusu yumağı kendisine vermesini ister)

$\left\{{ }^{*} \mathrm{bu} /{ }^{*} \mathrm{~s} \mathrm{u} / \mathrm{o}\right\}$ yumağı verir misin?

Örnek (1) ve (1')'deki şu ve $o$ sözcükleri, konuşma ortamında ilk kez bahsedilen bir gönderge olan yumağı işaretlemek için kullanılmaktadır. Bu örnekler arasındaki en önemli fark, söz konusu göndergenin bulunduğu alanın, dinleyicinin tek taraflı ilgisi dolayısıyla konuşucuya kapalı olup olmadığıdır. Yani, örnek (1')'de, dinleyici, nesneye yönelmiş olan konuşucunun ilgisinin farkında değildir. Bu durumu konuşucunun bakış açısından değerlendirdiğimizde, söz konusu nesnenin dinleyicinin tek taraflı ilgisinin hâkim olduğu alan içinde bulunduğunu söyleyebiliriz. Bu anlamda, göndergeyi içeren alanın konuşucuya kapalı olduğunu varsaymak mümkündür. Başka bir deyişle, örnek (1')'de, konuşucunun söz konusu göndergeye erişimi dinleyicinin algısal durumu tarafindan sınırlandırılmıştır. Bu duruma karşın, örnek (1)'deki gönderge, dinleyicinin ilgisi tarafından tek taraflı olarak domine edilen bir alan içinde değildir. Çünkü konuşucu, dinleyicinin ilgisinin söz konusu nesne üzerinde olmadığını farz etmektedir. Bu nedenle, (1)'de, göndergenin bulunduğu alanın konuşucuya açı olduğunu söylememiz mümkündür. Diğer bir deyişle, örnek (1)'de, konuşucunun nesneye serbest erişimi, dinleyicinin algısal durumu tarafından sınırlandırılmamıştır. Bütün bunlara ek olarak, örnek (1)'de işaret sözcüğü kullanımına gösterme/parmakla işaret etme eyleminin eşlik etmesi beklenirken, örnek (1')'de böyle bir eylemin uygun olmayacağı da görülmektedir. Bu bulgular ışı̆̆ında, örnek (1)'deki göndergenin konuşucunun alanı içinde, örnek (1')'deki göndergenin konuşucunun alanı dışında olduğunu söylememiz mümkündür. Eğer bu gözlemimiz doğruysa, Şekil 3'de belirtilen işaret sözcüğü ayrımı temel alındığında, (1)'deki nesneyi $b u / s ̧ u, ~\left(1^{\prime}\right)$ 'deki nesneyi $o$ ile işaretlememiz gerekir. Bu örneklerde de görüldüğü üzere, örnek (1)'de şu, örnek (1')'de de $o$ kullanılmaktadır. Aşağıdaki örnekte de, aynı şu ve o'nun kullanımında görüldüğü gibi, bu'nun dağılımını belirlemede konuşucunun alanı kavramının işlevsel olduğunu görülmektedir.

(2) (Kadın, kocasının kravatını bağlarken ona sorar)

$\left\{\mathrm{bu} /{ }^{*} \mathrm{~s} \mathrm{u} /{ }^{*} \mathrm{o}\right\}$ kravatı nereden aldın?

Örnek (2)'de, konuşucu (kadın), hem kendisinin hem de dinleyicinin (koca) gönderime konu olan nesneyle (kravat) ilgilendiğini varsaymaktadır. Bu da bize, bu örnekte, söz konusu nesnenin dinleyicinin tek taraflı ilgisi dolayısıyla konuşucuya kapalı olmayan bir alan içinde olduğunu göstermektedir. Yani, (2)'de, konuşucunun söz konusu göndergeye olan serbest erişimi dinleyicinin algısal durumu tarafından sınırlandırılmamıştır. Ayrıca, bu örnekte, $b u$ işaret sözcüğünün kullanımına, konuşucuya ait 
bazı jestler (örneğin, elindeki kravatı hafif havaya kaldırarak dinleyiciye gösterme gibi jestler) de eşlik edebilmektedir. Bu bulgular ışığında, örnek (1)'e benzer biçimde, örnek (2)'deki göndergenin de konuşucunun alanı içinde olduğunu söylememiz mümkündür. Ancak, bu yaklaşım, (yani bu ve şu sözcükleri konuşucunun alanı içindeki nesneyi işaretlemesi) şu soruyu da beraberinde getirmektedir: $B u$ ve şu işaret sözcüklerinin dağılımını belirleyen etmen ya da etmenler nelerdir? Balpınar (2014) bu soruyu dinleyicinin algısı kavramıyla açıklamaya çalışmaktadır. Aşağıdaki örneği inceleyelim.

(2') (Kadın kocasının kravatını bağlarken, ikisinden de biraz uzakta bulunan masanın üzerindeki kravatı göstererek)

$\left\{{ }^{*} \mathrm{bu} / \mathrm{şu} /{ }^{*} \mathrm{o}\right\}$ kravatı nereden aldın?

Örnek (2')'deki şu işaret sözcüğü, aynı örnek (2)'de olduğu gibi, yeni bir gönderge olan kravatı söylem ortamına getirmek için kullanılmaktadır. Göreceli mesafe dışında, bu örnekler arasındaki en önemli fark, dinleyicinin söz konusu göndergenin farkında olup olmadığıdır. Örnek (2)'de dinleyicinin göndergeyi fark ettiğini, örnek (2')'da ise henüz fark etmediğini söylemek mümkündür. Eğer bu gözlemimiz doğruysa, Balpınar (2014) tarafından oluşturulan işaret sözcüğü kavramsalı temel alındığında, (2)'deki nesneyi bu, (2')'deki nesneyi şu ile işaretlememiz gerekir. Bu örneklerde de görüldüğü üzere, örnek (2)'de bu, örnek (2')'de de şu kullanılmaktadır.

Son olarak, şu işaret sözcüğünün durumsal kullanımıyla ilgili olarak aşağldaki örneği inceleyelim.

(3) (Konuşucu A, konuşucu B’nin boynuna masaj yapmaktadır)

\section{A: Brrak boynumu.}

B: İyice bir yoğurayım.

A: Laf anlamaz misin, birak $\left\{{ }^{*} \mathrm{bu} / \mathrm{s} u /{ }^{*} \mathrm{o}\right\}$ boynumu!

(Öğüt, 2004, s. 117)

Örnek (3)'de, hem konuşucu A hem de konuşucu B farkında olmasına karşın, söz konusu gönderge (boyun) şu sözcüğüyle işaretlenmektedir. Bu açıdan, şu'nun örnek (3)'deki kullanımı, yukarıda belirttiğimiz genellememize (yani, şu'nun, dinleyicinin henüz fark etmediği nesneyi gösterdiğine ilişkin genellememize) ilk bakışta aykırıymış gibi görünebilir. Ancak, bu çeşit kullanımların, örnek (1) ve (2')'de verilen prototip kullanımlardan anlamsal genişleme yoluyla türediğini düşünmek mümkündür. Konuşucunun alanı kavramı açısından örnek (3)'e baktığımızda, aynı (1) ve (2')'de olduğu gibi, göndergenin (boyun) konuşucunun alanı içinde bulunduğunu söylemek mümkündür. Yani, (3)'de söz konusu gönderge konuşucu B’nin tek taraflı ilgisinin hâkim olduğu alan içinde olmadığından, konuşucu A'nın göndergeye serbest erişimi (ya da kullanımı) burada kısıtlanmamıştır. Ayrıca, bu örnekte, şu'nun kullanımına bazı gösterimsel eylemlerin eşlik etmesi de beklenebilir (örn. konuşucu A’nın, kendi boynu üzerindeki B'nin eline vurması gibi). Burada, örnek (1) ve (2')'deki şu'nun temel kullanımlarından farklı olarak, konuşucu B göndergeyi fark etmiş olmasına karşın, konuşucu A aynı göndergeyi sanki o fark etmemiş gibi ele almaktadır. Böylece, konuşucu A’nın, konuşucu B’ye karşı söz konusu göndergeyi daha belirgin ve baskılı bir biçimde işaret etmesi mümkün olabilmektedir. Şu'nun buna benzer kullanımlarını emir ve ünlem cümleleri içinde sıklıkla görmek mümkündür (daha çok örnek için bkz. Balpınar, 2006). 


\section{Algisal kullanım}

Algısal kullanım, konuşucunun, durum bağlamında bulunmayan ve dinleyiciyle arasındaki ortak bilgiye dayandırdığı bir olay, nesne/varlık ya da kişiye gönderimde bulunduğu işaret sözcüğü kullanımı olarak tanımlanabilir.5 Aşağıda (4)'de verilen cümle, bu türden bir işaret sözcüğü kullanımını içermektedir.

(4) (Konuşucu, Yakup denilen bir kişi hakkında konuştuktan sonra, yanındaki adamına şu emir verir)

Git $\left\{{ }^{*} \mathrm{bu} /\right.$ şu/* o Efraim’e bir soruştur bu Yakup denen adamı.

(Eldem, 2004, s. 65)

Örnek (4)'de, konuşucu, konuşma ortamında bulunmayan Efraim isimli arkadaşını hatırlayarak, yanındaki adamının da iyi bildiğini düşündüğü bu şahsı şu işaret sözcüğünün göndergesi yapmaktadır. Bunun gibi, konuşucunun ve dinleyicinin ortak bilgisine dayalı bir varlığın/nesnenin gönderge haline getirildiği durumlarda söz konusu göndergeyi işaretlemek için şu işaret sözcüğü kullanılabilmektedir. Buna benzer kullanımlarda, dinleyicinin söz konusu göndergeyi belirlemesine/tanımlamasına yardımcı olmak ve dolayısıyla gönderimsel davranışın başarıya ulaşabilmesi amacıyla, konuşucu işaret sözcüğünün kullanımı esnasında bazı niteleyici ifadelere başvurabilmektedir (ayrıca bkz. Hayasi, 2014, ss. 213-214). Bu durum örnek (5)’de gösterilmiştir.

(5) (Konuşucu dinleyiciye daha önce söz verdiği yemeği hatırlatır)

Haydi gidip, $\left\{{ }^{*} \mathrm{bu} /\right.$ şu/*0 $\}$ söz verdiğin akşam yemeğini yiyelim.

(5)'deki örnekte, aynı örnek (4)'de de görüldüŭü gibi, konuşucu, dinleyicinin de hatırladığını varsaydığı göndergeyi (yemek) şu sözcüğüyle işaretlemektedir. Örnek (4)'den farklı olarak, bu örnekte konuşucu, dinleyicinin hatırlamasına yardımcı olmak amacıyla söz konusu göndergeyi bir tümceyle (örnek (5)'de italikle belirtilmiş ifadeyle) nitelemekte ve böylece dinleyicinin göndergeyi mümkün olan diğer benzer göndergeler arasında tek bir göndergeye (yani token’a) indirgeyebilmesini sağlamaktadır.

Yukarıdaki örneklerdekine benzer bir durum, $o$ işaret sözcügünün kullanımında da görülmektedir. Örnek (6)'ya bir göz atalım.

(6) (Güzin Hakkı'dan hoşlanmaktadır ama bunu Hakkı'ya söyleyemez. Bir gün, Hakkı’nın yanında daha önce görmüş olduğu bir kız hakkında ona soru sorar.)

Güzin: Haydi, hem yürüyelim hem anlat. $\left\{{ }^{*} \mathrm{bu} /{ }^{*}\right.$ şu/o $\}$ gördüğüm kız mı?

Hakkı: Evet. (Sümer, 2006, s. 28, durum bağlamı değiştirilmiştir)

Burada, $o$ sözcüğüyle işaret edilen söz konusu gönderge (kız), aynı (4) ve (5)'deki örneklerde olduğu gibi, konuşmaya katılan her iki kişinin de iyi bildiği, durum bağlamında bulunmayan bir göndergedir. $\mathrm{Bu}$ örnek bize, aynı şu sözcüğünde olduğu gibi, o işaret sözcüğünün de algısal kullanım işlevine sahip olduğunu göstermektedir. ${ }^{6}$ Eğer bu gözlemimiz doğruysa, şu ve $o$ algısal işaret sözcüklerinin uygun

Ortak bilgi (shared information) kavramı için bkz. Clark \& Marshall (1981).

$B u$ işaret sözcüğü de, aynı şu ve $o$ sözcüklerinde olduğu gibi, durum bağlamında bulunmayan ama konuşucunun zihninde bulunan bir göndergeyi işaretlemek için kullanılabilir (bkz. örnek (i)). 
kullanımlarını belirleyen koşul ya da koşullar nelerdir sorusu üzerinde de durmamız gerekir. Bu sorunun cevabının, işaret sözcüklerinin durumsal kullanımında gördüğümüz konuşucunun alanı kavramında gizli olduğunu söyleyebiliriz. Konuyu biraz daha açalım. Örnek (6)'da, gönderim eylemi, diyalogda bulunan konuşmacıların geçmiş ortak tecrübesine dayalı olarak gerçekleştiğinden, ilk bakışta söz konusu gönderge (kız) konuşucunun alanı içindeymiş gibi görünmektedir. Ancak, bu örnekte, konuşucunun (Güzin) göndergeye serbest erişiminin ve aynı göndergeyi sorunsuz bir biçimde işaret edebilmesinin, konuşucunun (Güzin) psikolojik durumuyla sınırlandırılmış olduğunu söylemek mümkündür. Zira, Güzin, Hakkı'dan hoşlanmakta ve Hakkı'nın yanında gördüğü kızı psikolojik olarak kendisinden mümkün olduğunca uzaklaştırmaya çalışmaktadır. Böyle bir durumda, söz konusu gönderge, Güzin’in bakış açısından, erişimin psikolojik olarak sınırlandırıldı̆̆ı alan içinde kalmaktadır. Diğer bir deyişle, örnek (6)'da, göndergeye konu olan kız'ın konuşucunun alanı dışında olduğunu söylememiz mümkündür. Eğer bu yaklaşımımız doğruysa, Balpınar (2014)'e göre (bkz. Şekil 3), (6)'da göndergeyi işaretlemek için $o$ işaret sözcüğünün kullanılması gerekmektedir. Örnek (6)'da görüldüğü üzere, bahsedilen durumsal bağlamda sadece $o$ işaret sözcü̆ünün kullanımı geçerlidir.

Örnek (6)'da, konuşucunun göndergeye olan yaklaşımının (göndergeye karşı tutumunun), algısal kullanımda işaret sözcüğü dağglımına olan etkisini aşă̆ıdaki örnekte görmemiz mümkündür.

(6') (Güzin, ağabeyi Hakkı’nın yanında daha önce gördüğü bir kız hakkında ona bir soru sorar)

Güzin: Haydi, hem yürüyelim hem anlat. $\left\{{ }^{*} \mathrm{bu} /\right.$ şu/*o $\mathrm{o}$ gördüğüm kız mı?

Hakkı: Evet.

(6')'daki örnekte, konuşucu (Güzin) ağabeyi Hakkı'nın yanında gördüğü ve ona yakıştırdığı güzel bir kız hakkında soru sorar. Bu durumsal bağlam içinde, örnek (6)'dan farklı olarak, söz konusu göndergenin (kız), konuşucunun (Güzin) alanı içinde olduğu söylemek mümkündür. Başka bir ifadeyle, örnek (6')'da, konuşucunun (Güzin) göndergeye olan serbest erişimi, konuşucunun (Güzin) psikolojik durumu tarafından sınırlandırılmış değildir. Çünkü Güzin, ağabeyi Hakkıya söz konusu olan kızı yakıştırmakta ve ona karşı bir sempati duymaktadır. Eğer bahsettiğimiz gibi, (6')'daki gönderge konuşucunun alanı içindeyse, Balpınar (2014)'ün görüşüne göre aynı göndergeyi işaretlemek için şu en uygun seçenek olacaktır. Örnek (6')'da da görülebileceği gibi, böyle bir durumda sadece şu işaret sözcüğü kullanılmaktadır.

Son olarak, (4) ve (5)'deki örneklere de konuşucunun alanı kavramı açısından bir göz atalım. (4)'deki Efraim ve (5)'deki yemek, konuşucunun ve dinleyicinin her ikisinin de iyi bildiği (konuşucunun ve dinleyicinin her ikisinin de iyi bildiğini konuşucunun düşündüğü) göndergeler olup, bu göndergelere olan algısal (zihinsel) erişim konuşucunun psikolojik durumu tarafından sınırlandırılmış değildir. Bu açıdan, bu örneklerde konuşucunun bu göndergelere olan algısal erişiminin serbest olduğunu söyleyebiliriz. Bu bize, söz konusu göndergelerin, gönderimsel davranışın sorunsuzca yerine getirilmesi beklenen alan içinde olduklarını göstermektedir. Dolayısıyla, bu örneklerdeki göndergelerin konuşucunun alanı içinde bulunduğunu söylemek mümkündür.

(i) (Konuşucu, daha önce kendisini takip etmiş olan kadını hatırlayarak kendi kendine söylenir) $\left\{\mathrm{bu} /{ }^{*}\right.$ şu/o\} kadın benim kötülüğümü istiyor. (Eldem, 2004, s. 199)

Ancak, bu sözcüğünün bu şekilde kullanımı, şu ve $o$ sözcüklerinin kullanımlarından farklı olarak, dinleyicinin varlığını konuşucunun dikkate almadığı durumlarla sınırlıdır (örn. kişinin kendi kendine yüksek sesle konuşması gibi). Bu açıdan, bu sözcügünün, şu ve o'da görülen nesneyi dinleyiciye gösterme işlevine sahip olmadığını söylemek mümkündür. Bu nedenle, çalışmamızda, bu işaret sözcügünün bu çeşit kullanımları analiz dışı bırakılmıştır. 


\section{Metne bağlı kullanım}

Metne bağl kullanım, işaret sözcügünün, söylem içinde kendinden önce gelen bir tümceye ya da ad öbeğine gönderimde bulunduğu kullanım olarak tanımlamak mümkündür.7 Türkçe işaret sözcükleri üzerine yapılmış olan az sayıdaki çalışmada ve Türkçe üzerine yazılmış bazı dilbilgisi kitaplarında, $b u$ ve $o$ işaret sözcüklerinin, metne bağlı kullanım özelliğine dikkat çekilmektedir (Underhill, 1976; Kornfilt, 1997; Gencan, 2001; Kinsui vd., 2002; Nisioka, 2005). Ancak, bu çalışmalarda, sözel metin (söylem) içinde kullanılan $b u$ ve $o$ sözcüklerinin hangi dağılımsal özelliklere sahip olduğu hususu üzerinde durulmamaktadır. Bu bölümde, sözel metin içinde $b u$ ve $o$ işaret sözcüklerinin uygun kullanımını belirleyen koşullar irdelenecektir. ${ }^{8}$

Aşağıdaki örnekleri inceleyelim.

(7) A: Ben sizin hayranınızım.

B: $\{$ bunu/*onu $\}$ işitmek bir yazar olarak beni kıvançlandırır.

(Öğüt, 2004, s. 267)

(8) A: Benim için aşkınızdan daha mühim hiçbir şey yok.

B: Senin için $\left\{\mathrm{bu} /{ }^{*} \mathrm{o}\right\}$ doğru olabilir. Ama benim aşktan daha mühim işlerim var.

(Kulin, 2007, s. 233)

(7)'de belirtili nesne konumunda, (8)'deyse özne konumunda bulunan bu işaret sözcüklerinin göndergeleri, sırasıyla, kendinden önce gelen ve konuşucu A'ya ait sözce içindeki "benim sizin hayranınız olduğum" ve "benim için aşkınızdan daha mühim hiçbir şey olmadı̆̆ı" ifadeleridir. Bu örnekler bize, bildirişim sırasında sözce aracılı̆̆ıyla söylem ortamına aktarılan bir içeriğin (önermenin) gönderge yapıldığı durumlarda bu sözcüğünün işlevsel olduğunu göstermektedir.

Eğer bu düşünce doğruysa, aşağıda verilen örnekteki bu işaret sözcüğünün kullanımı nasıl yorumlanmalıdır?

(9) “Eser Abi, senin kırk yaşında olduğuna inanamıyorum ben, acayip genç gösteriyorsun.”

$\left\{\mathrm{bu} /{ }^{*} \mathrm{o}\right\}$ da bizim şirketteki genç programcllardan birinin repliği.

(Eldem, 2004, s. 138)

Örnek (9)'daki bu işaret sözcüğünün örnek (7) ve (8)'deki bu işaret sözcüklerinden farkı, bir önermeyi değil, bir alıntıyı işaretlemek için kullanılmasıdır. Başka bir deyişle, bu'yla işaret edilen öğe, alıntı cümlenin anlamsal içeriği değildir; alıntı cümlenin kendisidir. Buradaki söz konusu gönderge (alıntı),

\footnotetext{
$7 \quad$ Artgönderim/önyineleme (anaphora) terimi, genel olarak dilbilim literatüründe, eşgönderimli (eşdizinlenmiş) iki birim arasındaki bağıntıyı gösteren dilbilgisel ilişki olarak tanımlanmaktadır (bkz. Bussman, 1996, s. 58). Bu açıdan bakıldığında, bu çalışmada adı geçen metne bağh kullanım teriminin artgönderim/önyineleme terimine göre daha kapsayıcı olduğunu söylemek mümkündür.

8 Şu işaret sözcüğü, metne bağlı kullanım özelliği göstermediğinden, bu kısımda ele alınmamıştır.
} 
durumsal kullanımdakine benzer bir biçimde, sanki metin içinde göz önünde bulunan bir objeymiş gibi ele alınmaktadır. Aşağıda (10)'da verilen cümle de bu düşüncemizi destekler niteliktedir.

(10) “E” $\left\{\mathrm{bu} /{ }^{*} \mathrm{o}\right\}$ Türk lirasının simgesidir.

Örnek (10)'daki bu işaret sözcüğü, yazılı söylem içindeki dilsel bir işareti (TL simgesini) göstermektedir. Burada, söz konusu "E”" simgesinin gerçekte göz önünde bulunan (durum bağlamında varolan) bir nesne olmaması, onun gösterimsel özelliklere sahip olması gerekliliğini ortadan kaldırabilir. Ancak, bu tip metiniçi dilsel işaretleri, yazılı bağlamda göz önünde bulunan nesnelermiş gibi ele aldığımızda, doğrudan gösterime (durumsal kullanıma) benzer biçimde bunları işaret etmemiz pekâlâ da mümkün olabilmektedir.9 Lyons (1977) ve Ogawa (1986), bu özelliklerinden dolayı, bu tip işaret sözcüğü kullanımlarına metiniçi gösterim (textual deixis) adını vermektedir. Bu açıdan, (9) ve (10) numaralı örneklerdeki bu işaret sözcüğü kullanımını, dil dışı bağlamın (durumsal kullanımın) dil içi bağlama (metne bağlı kullanıma) genişlemesi yoluyla elde edilmiş gösterimsel kullanımın bir çeşidi olarak değerlendirmek mümkündür.

Son olarak, $o$ işaret sözcüğünün metne bağlı kullanım özelliklerine bir göz atalım.

(11) A: Bir derdin varsa şirkette görüşebilirdik.

B: Önce $\left\{{ }^{*}\right.$ buraya/oraya $\}$ gittim, yoktun.

(Sümer, 2003, s. 107)

(12) Ben bunca zamandır ölüme hazırdım, \{*bunu/onu $\}$ beklemekteydim.

(Mungan, 1992, s. 56)

(11)'de konuşucu A'nın sözcesi içindeki şirket sözcüğü ve (12)'de konuşucunun kendi ifadesi içindeki ölüm sözcüğü $o$ köklü işaret sözcükleriyle işaretlenmiştir. Bu örneklerden de anlaşlacağ gibi, (7) ve (8)'de gördüğümüz bu işaret sözcüğünün kullanımından farklı olarak, $o$ sözcüğü kendinden önce gelen bir ad öbeğiyle ilişkilendirilmektedir. ${ }^{10}$ Benzer bir yaklaşım, Nisioka (2006)'da da rapor edilmektedir. Nisioka, (a) konuşucunun kendi öncül sözcesi içindeki bir kurucuyu (constituent) ya da (b) karşıdaki konuşucunun (dinleyicinin) sözcesi içindeki bir kurucuyu o sözcüğünün işaretlediğini ileri sürmektedir. Ancak, yukarıdaki örneklerde de görüleceği üzere, o'nun öncülü (antecedent) olarak seçilen öğe, ön tümce içindeki herhangi bir kurucu unsur değil, sadece ön tümce içinde bulunan ad öbeği niteliğindeki yapıdır. ${ }^{11}$ Aşağıdaki işaret sözcüğü kullanımı da bu görüşümüzü destekler niteliktedir.

(13) Bir şeyin doğru olmaması, \{*bunun/onun\} yalan olduğunu göstermez ki.

\footnotetext{
9 (9) ve (10) numaralı örneklerde, söz konusu göndergelerin ișaret sözcüğünü içeren cümlenin sonuna alınması durumunda da bu'nun kullanılması mümkün olmaktadır (bkz. örnek $\left(9^{\prime}\right)$ ve $\left(10^{\prime}\right)$ ).

$\left(9^{\prime}\right) \quad\left\{\mathrm{bu} / \mathrm{şu}^{*} \mathrm{o}\right\}$ da bizim şirketteki genç programcllardan birinin repliği.

"Eser Abi, senin kırk yaşında olduğuna inanamıyorum ben, acayip genç gösteriyorsun."

$\left(10^{\prime}\right) \quad\{\mathrm{bu} /$ şu/*o\} Türk lirasının simgesidir. “Е”.

10 Burada, işaret sözcügünün bir öncülle ilişkilendirilmesi, işaret sözcüğ̈̈nün öncülüyle aynı dizin değeri alabilmesi (coindexation) anlamına gelmektedir.

${ }_{11} \quad$ Ad öbeği dış dünyaya ait herhangi bir nesneyi/olayı/durumu işaret edebilmesine karşın, ad tek başına bir nesneyi/olayı/durumu işaret edememektedir. Bunu, tanımlı̆g sahip dillerde, ad öbeğinin ve adın farklı biçimlerde ifade edilmesinden anlamak mümkündür. Örneğin, İngilizce $a /$ the car ifadesi bir ad öbeği yapısı olup ([Аӧ a/the [A car]]), car sözcüğü bu yapının niteliğini belirleyen kurucusu, yani başıdır (head).
} 
Örnek (13)'de o'yla işaretlenmiş olan gönderge, aynı (11) ve (12)'deki örneklerde olduğu gibi, söylem ortamına aktarılmış olan bir ad öbeği (yani [Ä̈ bir [A şey]]) yapısıdır. Bu örnekteki işaret sözcüğü kullanımının diğer iki örnekteki kullanımdan farkı, buradaki o'nun, bir niceleyici (quantifier) tarafından bağlanan mantıksal değişken (variable) olarak işlev görebilmesidir. ${ }^{12}$ Başka bir deyişle, örnek (11) ve (12)'deki $o$ tek bir göndergeye işaret etmesine karşın, (13)'deki o'nun değeri (anlamı) öncülün değerine bağlı olarak değişim gösterebilmektedir. Yani, (13)'de, “A şeyinin doğru olması A'nın yalan olduğunu göstermez, B şeyinin yalan olması B’nin yalan olduğunu göstermez, C şeyinin doğru olması...” gibi bir okumada, $o$ işaret sözcüğüne denk gelen kısmın değeri öncülün değerine bağlı olarak değişiklik gösterecektir. Böyle bir okumanın sadece ve sadece $o$ işaret sözcüğüyle mümkün olduğu örnek (13)'de açlk bir biçimde görülmektedir.

\section{Sonuç}

Bu çalışmada, Türkiye Türkçesindeki işaret sözcüklerinin çeşitli kullanımları, ilk kez, durumsal, algısal ve metne bağh kullanımlarına ayrılarak sistematik bir biçimde eş zamanlı açıdan incelenmiş ve bu sözcüklere ait bazı sözdizimsel, anlamsal ve edimsel özellikler açığa çıkartılmaya çalışılmıştır. Araştırmanın bulguları bize şunları göstermektedir: 1- Durumsal kullanımda (durum bağlamında bulunan nesneleri işaret eden kullanımda), (a) bu ve şu konuşucunun alanı içinde bulunan göndergeye işaret ederken, $o$ konuşucunun alanı dışında kalan göndergeye işaret eder (Balpınar, 2014), (b) şu, bu'dan farklı olarak, göndergeyi daha belirgin ve baskılı bir biçimde işaret edebilme özelliğine sahiptir. 2- Algısal kullanımda (konuşucunun ve dinleyicinin ortak bilgisine dayalı işaret sözcüğü kullanımda) da, (a) durumsal kullanımdakine benzer bir biçimde, bu ve şu konuşucunun alanı içinde bulunan göndergeye işaret ederken, $o$ konuşucunun alanı dışında kalan göndergeye işaret eder, (b) konuşucunun göndergeye ilişkin öznel tutumu, algısal kullanımda işaret sözcüğü dağılımını belirleyen etmenlerden birisidir. 3- Metne bağh kullanımda (işaret sözcüğünün, söylem içinde kendinden önce gelen bir tümceye ya da ad öbeğine gönderimde bulunduğu kullanımda), (a) bu kendinden önce gelen bir önermeyi, o kendinden önce gelen bir ad öbeğini işaretler, (b) bu işaret sözcüğü, aynı durumsal kullanımdakine benzer bir biçimde, söylem içindeki dilsel işaretleri gösterme (metiniçi gösterim) işlevine de sahiptir ve bu özellik dil dışı bağlamın dil içi bağlama genişlemesi yoluyla elde edilmiş gösterimsel kullanımın bir örneği olarak değerlendirilebilir, (c) $o$ sözcüğü, $b u$ işaret sözcü̆üünün metne bağlı kullanımında görülmeyen, mantıksal değişken olabilme özelliğine sahiptir. Bu bulgular ışığında Türkçe işaret sözcükleri dizge yapısıyla ilgili şunları söylemek mümkündür: (a) durumsal kullanımda, Türkçe işaret sözcükleri iki sırası bitişik olan ikili bir karşıtlık ilişkisi (yani, bu şu / o ilişkisi) sergilemektedir, (b) Türkçe işaret sözcüklerinin algısal ve metne bağlı kullanımlarında ise ikili karşıtlık dizgeleri (algısal kullanımda 'şu / o' ve metne bağlı kullanımda ‘ $b u$ / o' dizgeleri) göze çarpmaktadır.

\section{Teșekkür}

Türkçe işaret sözcüklerinin uygun kullanımlarını belirlemede yardımlarını esirgemeyen, Dilâra Balpınar, Murat Eral, Ümit Öztalay ve Alper Çam’a gönülden teşekkür ederim. Üretici dilbilgisi kuramına göre, örnek (13)'de belgisiz sıfat olarak kullanılan (herhangi) bir sözcüğ̈ünün, mantıksal
düzeyde (logical form) bir işleyici (operator) gibi hareket ettiği ve değişkeni (yani o sözcüğünü) bağladığı düşünülebilir. 


\section{Kaynakça}

Balpınar, M. (2006) Bu-şu-o no Imi Kino to Torukogo ni okeru Sijishi Taikei ni tsuite [Bu-şu-o'nun Anlamsal İşlevi ve Türkçe İşaret Sözcükleri Sistemi Üzerine] (Yüksek lisans tezi). Reitaku Üniversitesi, Chiba, Japonya.

Balpınar, M. (2014). Torukogo sijishi ni okeru hibunmyaku siji yōhō no saikentō [Türkçe işaret sözcüklerinin metne bağlı olmayan kullanımlarının yeniden incelenmesi]. Tōkyō Daigaku Gengogaku Ronshū, 35, 21-39.

Banguoğlu, T. (2004). Türkçe’nin Grameri. Ankara: Türk Dil Kurumu.

Bastuji, J. (1976). Les relations spatiales en turc contemporain; étude sémantique. Paris: Éditions Klincksieck.

Bazin, L. (1968). Introduction à l'étude pratique de la langue turque (troisième édition revue et corrigée, 1987). Paris: Librairie d'Amérique et d'Orient, Adrien Maisonneuve.

Bussman, H. (1996). Dictionary of Language and Linguistics. London and New York: Routledge.

Clark, H. H., \& Marshall, C. R. (1981). Definite reference and mutual knowledge. A. K. Joshi, B. L. Webber, \& I. A. Sag, Elements of discourse understanding (ss. 10-63). Cambridge: Cambridge University Press.

Eldem, B. (2004). Seni Tilsımlar Korur. İstanbul: İnkılâp.

Ergin, M. (1958). Türk dil bilgisi. İstanbul: İstanbul Üniversitesi Edebiyat Fakültesi.

Gencan, T. N. (2001). Dilbilgisi. Ankara: Türk Dil Kurumu.

Hayasi, T. (1985). Torukogo no sijishi [Türkçe işaret sözcükleri]. Ajia \& Afurika gengo bunka kenkyūjo tsūshin, 53, 55-57.

Hayasi, T. (1988). On Turkish Demonstratives. Tokyo university linguistic papers, 88, 229-238.

Hayasi, T. (1989). Torukogo no susume 3: 'kore-sore-are' arekore [Türkçe'den öneriler 3: 'kore, sore, are' arekore]. Gengo, 18(1), 96-101.

Hayasi, T. (2014). Temporal characteristics of the Turkish demonstrative şu. N. Demir, B. Karakoç \& A. Menz, Turkology and Linguistics: Éva Ágnes Csató Festschrift (ss. 209-217). Ankara: Hacettepe Üniversitesi.

Iinuma, E. (1995). Torukogo Kiso [Temel Türkçe]. Tōkyō: Besutosha.

Kinsui, S., Okazaki, T., \& Jo, M. (2002). Sijigo no rekishiteki-taishō gengogakuteki kenkyū: NihongoKankokugo-Torukogo [İşaret sözcüklerinin tarihsel-karşılaştırmalı dilbilimsel araştırması: Japonca-Korece-Türkçe]. N. Ogoshi, Sirīzu gengo kagaku 4 taishō gengogaku [Dil bilimi serisi 4 karşılaştırmalı dilbilim] (ss. 217-247). Tōkyō: Tōkyō Daigaku Shuppankai.

Kissling, H. J. (1960). Osmanisch-Türkische grammatik. Wiesbaden: Otto Harrassowitz.

Kornfilt, J. (1997). Turkish. London: Routledge.

Kulin, A. (2007). Veda. İstanbul: Everest.

Lewis, G. L. (1967). Turkish grammar. Oxford: Oxford University Press.

Lyons, J. (1977). Semantics 2. London: Cambridge University Press.

Mungan, M. (1992). Taziye. İstanbul: Metis.

Nisioka, I. (2005). Türkçe ve Kazakça İşaret Sözcüklerinin Karşılaştırmalı Araştırması. M. Sarı \& H. Nas, XIX. Ulusal Dilbilim Kurultayı Bildirileri (ss. 222-233). Şanlıurfa: Elif Matbaası.

Nisioka, I. (2006). Gendai Churuku shogo no sijisi no kenkyū [Günümüz Türki Dillerindeki İşaret Sözcükleri Üzerine Bir Çalışma] (Doktora tezi). Kyūshū Üniversitesi, Fukuoka, Japonya.

Ogawa, H. (1986). Tekisutoteki chokuji hyōgen [Metinsel gösterim ifadeleri]. Eigo Seinen, 132(4), 165.

Ögüt, T. Y. (2004). 100 Diyalog. İstanbul: Mitos Boyut. 
Sümer, D. (2003). Toplu Oyunları 3. İstanbul: Mitos Boyut.

Sümer, G. (2006). Bütün Oyunları 3. İstanbul: Mitos Boyut.

Underhill, R. (1976). Turkish Grammar. Cambridge, MA: MIT Press. 